\title{
Effect of storage period on the chemical composition and sensory attributes of strawberry syrup
}

\author{
Singh, A., Kaushal, N. 四, Gill, H. S., Sood, N., Singh, T.
}

Received: 12.10.2020

Revised: 06.01.2021

Accepted: 13.01.2021

\begin{abstract}
The present study was carried out to develop syrup and standardise the formulation of recipe produced from strawberry and determine syrup's nutritional value during storage in the department of Agriculture, Mata Gujri College, Fatehgarh Sahib, Punjab during the winter season of 2018-2019. It was Fresh ripe strawberries were washed with pure water and blended to get the pulp. The fruits were analysed to determine the moisture, TSS, pH, ascorbic acid, total sugar, reducing sugar, titrable acidity and $\beta$ - carotene. Different combinations of table sugar and distilled water were used to prepare syrup with a constant value of $25 \%$ fruit pulp, i.e. $T_{1}=10 \%$ sugar concentration, $T_{2}=20 \%$ sugar, $T_{3}=30 \%$ sugar, $T_{4}=$ $40 \%$ sugar, $T_{5}=50 \%$ sugar, $T_{6}=60 \%$ sugar, $T_{7}=70 \%$ sugar with $25 \%$ strawberry pulp and $T_{8}$ with $25 \%$ pulp only. The samples were stored at ambient temperature for 120 days to check the physiochemical and organoleptic analysis of strawberry syrup. According to the opinion of organoleptic test panel, treatment with $60 \%$ sugar was the most preferred one after considering the points of colour, flavour, texture, taste, and overall acceptability. During storage period TSS, pH, total sugar and reducing sugar increased whereas titrable acidity and ascorbic acid content decreased during the storage period.
\end{abstract}

Key Words: Ambient temperature, physiochemical analysis, strawberry, syrup

\section{Introduction}

Strawberry (Fragaria $x$ ananassa Duch.) $(2 \mathrm{n}=56)$ belongs to family Rosacea. Strawberry is the most fascinated fruit in the world. Being rich in vitamins, minerals and antioxidant compounds with whooping returns, it has significant benefits for fruit consumers and growers as well (Hannum, 2004). Strawberry is cultivated in India over 500 hectare with a production of 3800 metric tonnes (Anonymous, 2017). Ripe strawberry consists of roughly $90 \%$ water and $10 \%$ total soluble solids (TSS). The fresh strawberry fruit contains protein, fat and carbohydrates contents of $0,7 \mathrm{~g}, 0.4 \mathrm{~g}$ and $8.5 \mathrm{~g} / 100 \mathrm{~g}$, respectively in addition to being a rich source of retinol $(60 \mathrm{IU})$, thiamine $(0.3 \mathrm{mg})$, riboflavin $(0.07 \mathrm{mg})$ and niacin $(0.6 \mathrm{mg})$ per $100 \mathrm{~g}$ FW (F.A.O., 2009). Strawberries are also an important source of phytochemicals, especially phenols responsible). for its antioxidant value among all the fruits (Cordenunsi et al., 2005). Postharvest losses of fruits in our country are appraised to be 20-30\% (Saigal and Omesh, 2001). The strawberry has a high cellular respiration rate,

\section{Author's Address}

Department of Agriculture, Mata Gujri College, Fatehgarh Sahib, Punjab

E-mail.: leo.naveet@gmail.com and therefore, it is highly perishable. To reduce the post-harvest losses in strawberry, its fruits can be processed to products including dehydrated candies, extracts, syrups, crushes, jams, bars and wines etc. These handy products of strawberry are ubiquitous amongst children due to their enticing colour and unique whiff. Strawberry is a nonclimacteric fruit, and due to its short storage life, a little work has been done in India on the handling of strawberry.

\section{Material and Methods \\ Raw Material}

Ripe strawberries used in the research were of Chandler cultivar. The strawberries were harvested at their corporal maturity, taking the parameters like colour and size.

Preparation of strawberry pulp

Healthy and ripe strawberry fruits of steady size and colour were selected. The calyx was removed, and the berries are separated. Fruits were weighed by using an electronic balance, washed thoroughly with pure water to remove any dirt or particles. The fruits were mashed in a pulper, and hence the pulp was prepared. 


\section{Preparation of sugar syrup}

Syrup of three different concentrations viz., $50^{\circ}$, $60^{\circ}$ and $70^{\circ}$ Brix was prepared by adding required amount of sugar in distilled water, and the total soluble solids of prepared syrup were determined by hand refractometer of various ranges $(0-32,28$ 62 and $58-92^{\circ}$ Brix). The concentration of sugar syrup was adjusted, either by heating or addition of sugar while boiling the sugar syrup solution. Citric acid @ 0.2\% and potassium metabisulphite (KMS) (a) $1 \%$ were added as preservatives by dissolving in little distilled water after the syrup was cooled.

\section{Preservation treatments of syrup}

Strawberry crush was divided into the seven lots viz. T1, T2, T3, T4, T5, T6 and T7 with standard laboratory safety measures. They were stored at ambient temperature with different requirement. Pre-sterilized glass bottles were used for the packing of all the strawberry syrups.

Physiochemical analysis of fresh strawberries and strawberry syrup

Fruit weight was calculated by taking the weight of fruit on electronic weighing balance and was determined as an average of fruits and is expressed in grams (g). Length and breadth of fruit were recorded with the help of digital vernier callipers and was expressed in millimetres $(\mathrm{mm})$. The $\mathrm{pH}$ and TSS content of syrup were determined as per the method of AOAC (2002). The $\mathrm{pH}$ was measured by $\mathrm{pH}$ meter, and the TSS was measured by placing a few drops of sample on the prism of a refractometer, and the direct reading was taken. Titratable acidity was measured by titration method cited by Ranganna (1995). Total sugar was measured by phenol - sulphuric acid method of Dubois et al. (1956) using glucose as standard. Reducing sugars were estimated by the method of Miller et al. (1972). The Phenols were estimated by Malik et al. (1980). Estimation of vitamin-C (ascorbic acid) content was brought by Rangana, $\mathrm{S}$. (1986).

\section{Sensory Evaluation}

A nine-point hedonic scale was designed to facilitate the sensory evaluation of the prepared product. Various sensory parameters like colour, flavour, uniformity, tang and overall acceptability were considered by the panel of eight semi-trained judges. Samples were hand over to the jurist the way they are normally ingested. Hidden samples were hand over to the judges in separate chambers or places to get unbiased acumen.

\section{Statistical analysis}

Data on physico-chemical characteristics were analysed by completely randomized design (CRD). The experiments conducted in this study were replicated thrice.

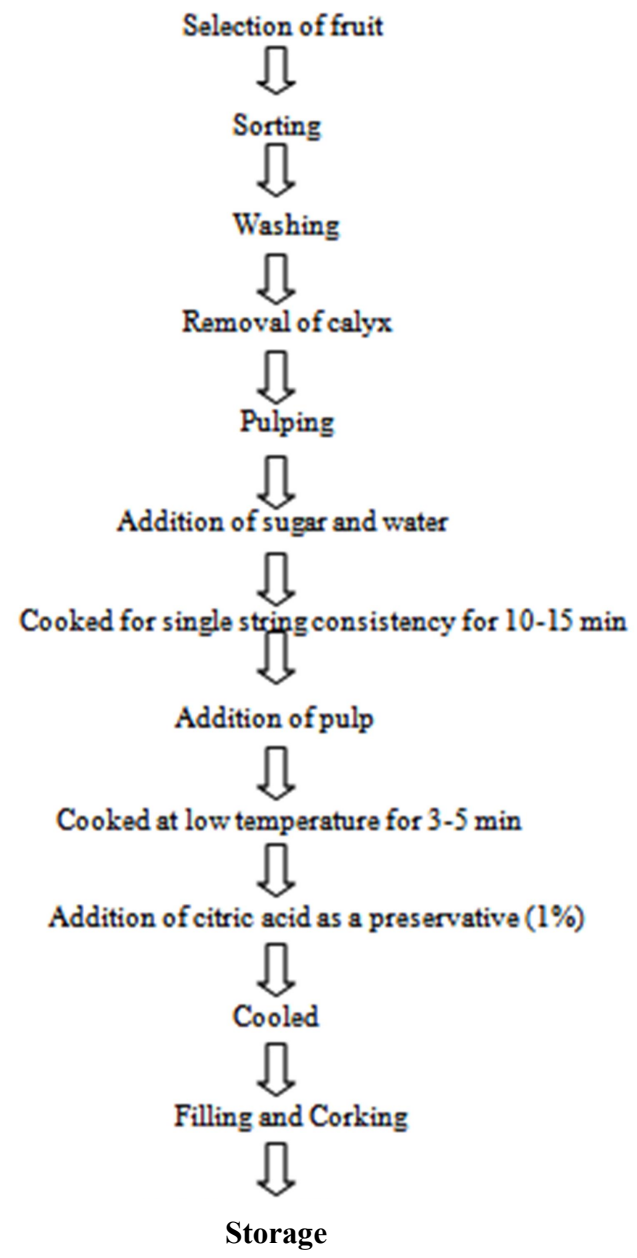

Figure 1. Flow chart for the preparation of Strawberry syrup

\begin{tabular}{|c|c|}
\hline Treatments & Combinations \\
\hline $\mathrm{T}_{1}$ & $25 \%$ pulp $+10 \%$ sugar \\
\hline $\mathrm{T}_{2}$ & $25 \%$ pulp $+20 \%$ sugar \\
\hline $\mathrm{T}_{3}$ & $25 \%$ pulp $+30 \%$ sugar \\
\hline $\mathrm{T}_{4}$ & $25 \%$ pulp $+40 \%$ sugar \\
\hline $\mathrm{T}_{5}$ & $25 \%$ pulp $+50 \%$ sugar \\
\hline $\mathrm{T}_{6}$ & $25 \%$ pulp $+60 \%$ sugar \\
\hline $\mathrm{T}_{7}$ & $25 \%$ pulp $+70 \%$ sugar \\
\hline $\mathrm{T}_{8}($ Control $)$ & $25 \%$ pulp only \\
\hline
\end{tabular}




\section{Results and Discussion}

Physiochemical properties of fresh strawberry fruit

The determined physico-chemical characteristics of fresh strawberry fruits which were used for the preparation of syrup are given in Table 1. The data on physico-chemical parameters of fresh strawberry fruits revealed the mean length, breadth and weight in the range of $29.3 \mathrm{~cm}, 23.7 \mathrm{~cm}$ and $7.72 \mathrm{~g}$ respectively. Further, data on chemical parameters of fresh strawberry syrup revealed mean TSS, acidity, $\mathrm{pH}$, reducing sugars, total sugars, ascorbic acid content in the range of $8.48^{\circ} \mathrm{B}, 1.25 \%, 3.52$ $\mathrm{pH}, 4.26 \%, 5.19 \%,, 45.71 \mathrm{~g}$, respectively.

Effect of preservation methods and storage period of strawberry syrup on TSS, acidity and pH.

TSS of strawberry syrup during four months storage has been presented in Table 2. Data revealed that mean TSS of strawberry syrup prepared by mixing different proportion of strawberry pulp with various sugar concentration varied significantly from 60.05 to $60.78^{0} \mathrm{~B}$ after four-month storage, with the minimum TSS (60.31) in strawberry syrup prepared using $\mathrm{T}_{1}(25 \%$ pulp + $10 \%$ sugar) and the maximum TSS (60.45) in syrup using $\mathrm{T}_{6}(25 \%$ pulp $+60 \%$ sugar $)$, which is statistically followed with $\mathrm{T}_{5}(25 \%$ pulp $+50 \%$ sugar) value of 60.43 and $\mathrm{T}_{7}$ (25\% pulp $+70 \%$ sugar) with a value of 60.40 . It is observed that there was a progressive increase in TSS (60.05 to $60.78^{0} \mathrm{~B}$ ) of strawberry syrup during storage. This increase in TSS of strawberry syrup during storage was probably due to partial hydrolysis of complex carbohydrates into simple sugar. There was a conversion of insoluble polysaccharides and organic acids into sugars. The $\mathrm{pH}$ patterns of syrup during four months of storage have been presented in Table 2. Mean $\mathrm{pH}$ of syrup prepared by mixing different proportion of strawberry pulp with various sugar concentration varied increases significantly after four-month storage, with minimum $\mathrm{pH}$ (2.71) in syrup prepared using $\mathrm{T}_{1}(25 \%$ pulp $+10 \%$ sugar $)$ and maximum $\mathrm{pH}(2.83)$ in syrup using $\mathrm{T}_{6}(25 \%$ pulp $+60 \%$ sugar), which is statistically followed with $\mathrm{T}_{5}(25 \%$ pulp $+50 \%$ sugar) value of 2.80 and $\mathrm{T}_{7}(25 \%$ pulp $+50 \%$ sugar $)$ value of 2.78 . The fruit pulp $\mathrm{pH}$ emerged as the most important attribute envisaging clearly the qualitative merit of strawberry syrup. The $\mathrm{pH}$ of the strawberry syrup has revealed that there was a slight increase in $\mathrm{pH}$ value 2.44 to 3.10 after four months of storage. The increase in $\mathrm{pH}$ or decrease in acidity can presumably be in part due to the copolymerisation of organic acids and the formation of brown pigments. The observed results are in conformity with those of Buglione and Lozano (2002).

From the above result, it is observed in general that, there was a decrease (1.43\% to $1.19 \%)$ in titratable acidity of strawberry syrup during storage due to recipe, storage conditions and interaction. The decline in titratable acidity of strawberry syrup during storage might be due to chemical interactions between organic constituents of strawberry fruit pulp induced by temperature and action of enzymes during storage. Salari et al. (2012) noticed a decreasing acidity trend during four-month of the storage period of muskmelon blended pomegranate syrup and squash.

Effect of preservation methods and storage period of strawberry syrup on reducing sugar, total sugar and ascorbic acid.

Reducing sugars of syrup during four months of storage has been presented in Table 3. Scrutiny of data clearly indicated that mean reducing sugar of strawberry syrup prepared by mixing the different strawberry pulp with various sugar concentration varied significantly from $21.12 \%$ to $26.11 \%$ after four months storage, with minimum reducing sugar $(23.53 \%)$ in syrup prepared using $\mathrm{T}_{1}(25 \%$ pulp + $10 \%$ sugar) and maximum reducing sugar (24.08 $\%)$ in syrup using $\mathrm{T}_{4}(25 \%$ pulp $+40 \%$ sugar. From the above result, it is observed in general that, there was a progressive increase $(21.12 \%$ to $26.11 \%)$ in reducing sugars of strawberry syrup during storage. The increase in reducing sugars of strawberry syrup during storage was probably due to gradual loss of moisture and hydrolysis of polysaccharides into sugars. Total sugars of syrup during four months of storage have been presented in Table 5. Scrutiny of data clearly indicated that mean total sugar of strawberry syrup prepared by mixing the strawberry pulp with various sugar concentration varied significantly increase from $54.55 \%$ to $60.73 \%$ after four months storage, with minimum total sugar $(57.09 \%)$ in syrup prepared using $\mathrm{T}_{2}(25 \%$ pulp $+20 \%$ sugar) and maximum total sugar (57.79 $\%)$ in syrup using $\mathrm{T}_{5}(25 \%$ pulp $+50 \%$ sugar $)$. 
Singh et al.

Table 1. Physicochemical properties of strawberry

\begin{tabular}{|c|l|c|c|c|}
\hline SN & Parameter & Respective values of strawberry & Standard error & CD \\
\hline 1 & Fruit length $(\mathrm{mm})$ & 29.3 & 1.12 & 3.34 \\
\hline 2 & Fruit breadth $(\mathrm{mm})$ & 23.7 & 0.59 & 1.76 \\
\hline 3 & Fruit weight $(\mathrm{g})$ & 7.72 & 0.94 & 2.84 \\
\hline 4 & $\beta$ carotene $(\mu \mathrm{g} / 100 \mathrm{~g})$ & 2.19 & 1.46 & 4.35 \\
\hline 5 & TSS $\left({ }^{\circ} \mathrm{B}\right)$ & 8.48 & 0.86 & 2.56 \\
\hline 6 & $\mathrm{pH}$ & 3.52 & 1.34 & 3.99 \\
\hline 7 & Anthocyanin $(\mathrm{m} / 100 \mathrm{~g})$ & 61.73 & 4.21 & 12.56 \\
\hline 8 & Titrable acidity $(\%)$ & 1.25 & 1.55 & 4.62 \\
\hline 9 & Ascorbic acid $(\mathrm{mg} / 100 \mathrm{~g})$ & 45.71 & 2.68 & 7.99 \\
\hline 10 & Reducing sugar $(\%)$ & 4.26 & 1.27 & 3.78 \\
\hline 11 & Total sugar $(\%)$ & 5.19 & 1.18 & 3.52 \\
\hline
\end{tabular}

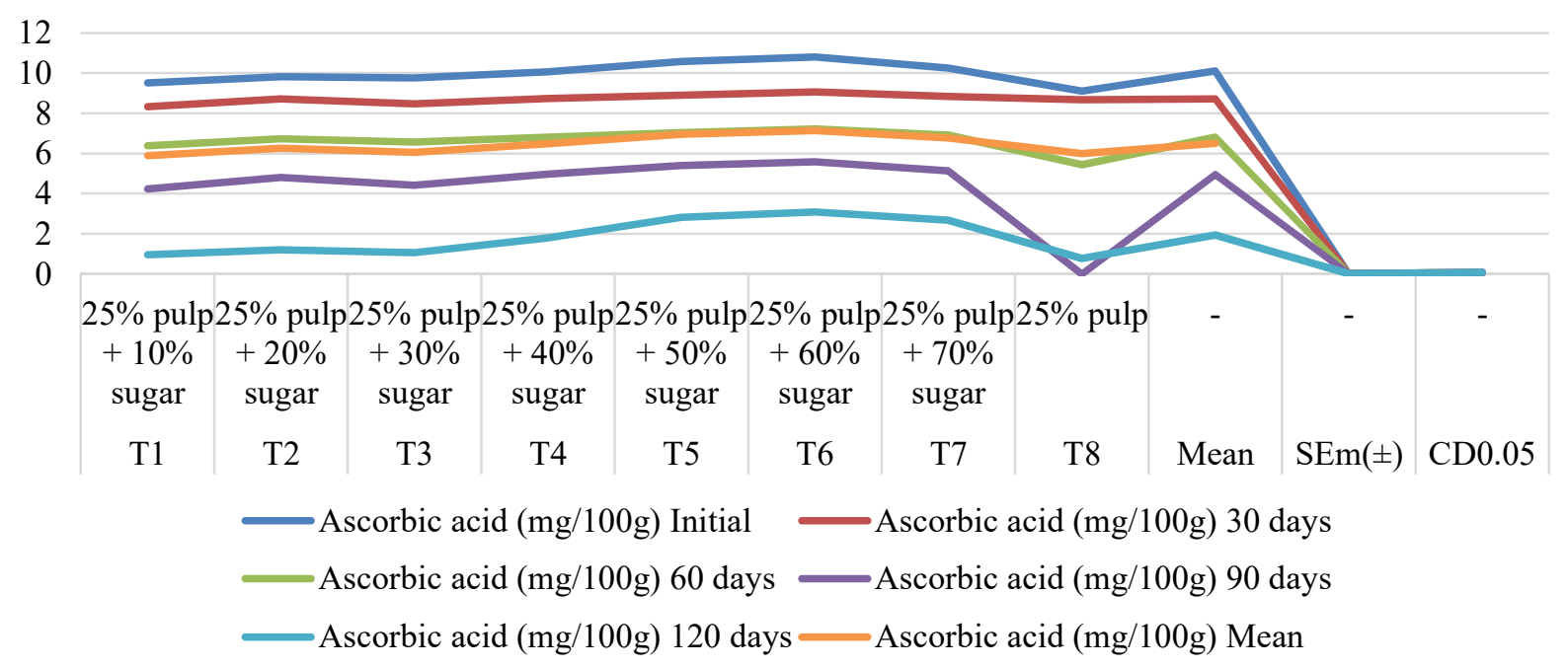

Figure 1. Changes in ascorbic acid $\left(\mathrm{mg}^{\left.100 \mathrm{~g}^{-1}\right)}\right.$ in all the treatments during four-month of the storage period

Ascorbic acid of strawberry syrup during four months storage has been presented in Fig1. The mean value of ascorbic acid was significantly decreased from $10.80 \mathrm{mg}$ to $0.96 \mathrm{mg}$ after fourmonth storage, with minimum ascorbic acid (5.89 $\mathrm{mg})$ in syrup prepared using $\mathrm{T}_{1}(25 \%$ pulp $+10 \%$ sugar) and maximum ascorbic acid $(7.15 \mathrm{mg})$ in syrup using $\mathrm{T}_{6}(25 \%$ pulp $+60 \%$ sugar $)$, which is statistically followed with $\mathrm{T}_{5}(25 \%$ pulp $+50 \%$ sugar) value of $6.95 \mathrm{mg}$ and $\mathrm{T}_{7}(25 \%$ pulp $+70 \%$ sugar) with a value of $6.77 \mathrm{mg}$. The experiment findings in the present research trait showed a progressive decrease $(10.80 \mathrm{mg}$ to $0.96 \mathrm{mg})$ in ascorbic acid of strawberry syrup during storage. The reduction in ascorbic acid of strawberry syrup during storage was probably due to the fact that ascorbate being sensitive to oxygen, light and heat was easily oxidised in the presence of oxygen by both synthetic and non-synthetic catalyst. Viberg et al. (1999) reported a decrease in ascorbic acid after treatment like frosty, warm-up and accelerated storage. These results are in agreement with the findings of Nunes et al. (1995), who recorded a change in Chandler variety of strawberries stored at $4^{\circ} \mathrm{C}$. 
Effect of storage period on the chemical composition

Table 2. Physico-chemical changes during four months of the storage period

\begin{tabular}{|c|c|c|c|c|c|c|c|c|c|c|c|c|c|}
\hline \multirow[b]{2}{*}{ SN } & \multirow[b]{2}{*}{ Treatments } & \multicolumn{3}{|c|}{ TSS } & \multicolumn{3}{|c|}{ pH (\%) } & \multicolumn{3}{|c|}{ Titrable acidity (\%) } & \multicolumn{3}{|c|}{ Total sugar (\%) } \\
\hline & & Initial & $\begin{array}{c}120 \\
\text { days }\end{array}$ & Mean & Initial & $\begin{array}{c}120 \\
\text { days }\end{array}$ & Mean & Initial & $\begin{array}{c}120 \\
\text { days }\end{array}$ & Mean & Initial & $\begin{array}{c}120 \\
\text { days }\end{array}$ & Mean \\
\hline $\mathbf{T}_{1}$ & $\begin{array}{l}25 \% \text { pulp }+ \\
10 \% \text { sugar }\end{array}$ & 2.44 & 2.98 & 2.71 & 2.44 & 2.98 & 2.71 & 1.38 & 1.02 & 1.19 & 54.6 & 60.15 & 57.27 \\
\hline $\mathbf{T}_{2}$ & $\begin{array}{l}25 \% \text { pulp }+ \\
20 \% \text { sugar }\end{array}$ & 2.47 & 3.03 & 2.75 & 2.47 & 3.03 & 2.75 & 1.42 & 1.05 & 1.22 & 54.6 & 59.79 & 57.09 \\
\hline $\mathbf{T}_{3}$ & $\begin{array}{l}25 \% \text { pulp }+ \\
30 \% \text { sugar }\end{array}$ & 2.46 & 3.01 & 2.73 & 2.46 & 3.01 & 2.73 & 1.4 & 1.04 & 1.23 & 54.6 & 60.28 & 57.37 \\
\hline $\mathbf{T}_{4}$ & $\begin{array}{l}25 \% \text { pulp }+ \\
40 \% \text { sugar }\end{array}$ & 2.5 & 3.04 & 2.77 & 2.5 & 3.04 & 2.77 & 1.43 & 1.06 & 1.23 & 54.6 & 59.98 & 57.19 \\
\hline $\mathbf{T}_{5}$ & $\begin{array}{l}25 \% \text { pulp }+ \\
50 \% \text { sugar }\end{array}$ & 2.52 & 3.07 & 2.8 & 2.52 & 3.07 & 2.8 & 1.46 & 1.09 & 1.27 & 54.7 & 60.73 & 57.79 \\
\hline $\mathbf{T}_{6}$ & $\begin{array}{l}25 \% \text { pulp }+ \\
60 \% \text { sugar }\end{array}$ & 2.53 & 3.1 & 2.83 & 2.53 & 3.1 & 2.83 & 1.48 & 1.1 & 1.29 & 54.6 & 60.37 & 57.49 \\
\hline $\mathbf{T}_{7}$ & $\begin{array}{l}25 \% \text { pulp }+ \\
70 \% \text { sugar }\end{array}$ & 2.51 & 3.04 & 2.78 & 2.51 & 3.04 & 2.78 & 1.44 & 1.07 & 1.25 & 54.7 & 60.52 & 57.61 \\
\hline $\mathbf{T}_{8}$ & $25 \%$ pulp & 2.41 & 2.88 & 2.64 & 2.39 & 2.81 & 2.60 & 1.31 & 0.89 & 1.10 & 52.78 & 57.33 & 55.05 \\
\hline Mean & - & 2.48 & 3.01 & 2.75 & 2.47 & 3.01 & 2.74 & 1.41 & 1.04 & 1.22 & 54.39 & 59.89 & 57.10 \\
\hline $\begin{array}{c}\text { SEm } \\
( \pm) \\
\end{array}$ & - & 0.02 & 0.02 & & 0.02 & 0.02 & & 0.02 & 0.02 & & 0.02 & 0.02 & \\
\hline $\begin{array}{c}\mathrm{CD}_{0.0} \\
5 \\
\end{array}$ & - & 0.05 & 0.07 & & 0.05 & 0.07 & & 0.05 & 0.07 & & 0.05 & 0.07 & \\
\hline
\end{tabular}


Table 3: Sensory evaluation of all the treatments : Singh et al. Jaration

\begin{tabular}{|c|c|c|c|c|c|}
\hline \multirow{2}{*}{ SN } & \multirow{2}{*}{$\begin{array}{c}\text { Treatments } \\
\text { (Conc.) }\end{array}$} & \multicolumn{3}{|c|}{ Sensory evaluation (9 points Hedonic scale) } \\
\cline { 3 - 5 } & & $\begin{array}{c}\text { Colour } \\
\text { and Appearance }\end{array}$ & $\begin{array}{c}\text { Taste and } \\
\text { mouthfeel }\end{array}$ & Flavour & $\begin{array}{c}\text { Overall } \\
\text { acceptability }\end{array}$ \\
\hline $\mathrm{T}_{1}$ & $25 \%$ pulp + 10\% sugar & 6.74 & 6.77 & 6.47 & 6.28 \\
\hline $\mathrm{T}_{2}$ & $25 \%$ pulp + 20\% sugar & 6.92 & 6.91 & 6.54 & 6.57 \\
\hline $\mathrm{T}_{3}$ & $25 \%$ pulp + 30\% sugar & 7.10 & 7.18 & 6.75 & 6.68 \\
\hline $\mathrm{T}_{4}$ & $25 \%$ pulp + 40\% sugar & 7.47 & 7.34 & 6.81 & 6.82 \\
\hline $\mathrm{T}_{5}$ & $25 \%$ pulp + 50\% sugar & 7.61 & 7.69 & 6.95 & 7.02 \\
\hline $\mathrm{T}_{6}$ & $25 \%$ pulp + 60\% sugar & 7.75 & 7.85 & 7.12 & 7.17 \\
\hline $\mathrm{T}_{7}$ & $25 \%$ pulp + 70\% sugar & 7.56 & 7.44 & 6.89 & 6.94 \\
\hline $\mathrm{T}_{8}$ & $25 \%$ pulp only & 6.00 & 6.56 & 6.67 & 6.56 \\
\hline
\end{tabular}

\section{Sensory evaluation}

The perusal of data pertaining to the effect of different treatments on sensory evaluation ( 9 points Hedonic scale) of strawberry syrup during four months storage has been presented in Table 8. Data revealed that the maximum sensory overall acceptability score (7.17) amongst all the treatments was gained in $\mathrm{T}_{6}(25 \%$ pulp $+60 \%$ sugar), which is statistically followed with $\mathrm{T}_{5}(25 \%$ pulp $+50 \%$ sugar) score (7.02) and $\mathrm{T}_{7}(25 \%$ pulp + $70 \%$ sugar) score (6.94). Minimum score occur (6.28) was followed in $\mathrm{T}_{1}$ (25\% pulp $+10 \%$ sugar). Totad et al., (2014) reported that sapota blended with jack fruit and avocado syrup was found to be acceptable with a good organoleptic score for

\section{References}

Anonymous. 2017. NHB Data Base. http://www.nhb.gov.in

Akhtar and Rab A.2015. Effect of irrigation intervals on the quality and storage. The journal of Animal and Plant Science, 25(3):669-678.

A.O.A.C. 2002. Association of Official Analytical Chemists, (16) Official Methods of Analysis, Washington, D.C. USA.

Biswas, M. K., Dutt, M., Roy, U. K., Islam, R. and Hossain, M. 2009. Development and evaluation of two in vitro somaclonal variation in strawberry for improved horticultural traits. Journal of Science Horticulture, 122(3): 409-416.

Caputi, A. and Wright 1969. Collaboration study for the determination of ethanol in wine by chemical oxidation. appearance, aroma taste and flavour and overall acceptability.

\section{Conclusion}

The findings summarised above indicate that strawberry syrup prepared using $\mathrm{T}_{6}(25 \%$ pulp + $60 \%$ sugar) stored under ambient storage was found superior in every aspect up to 120 days. The prepared product has not only increased the shelf life of this highly beneficial perishable fruit but also ensures the availability of healthy nutrients for the consumers. In contemporary times, this product is also a hope to excel in processing for a new enterprise ensuring huge profits.

Journal Association of official Analytical Chemists, 52: 85.

Cordenunsi, B. R., Genovese, M. I., Do Nascimento, J. R.O., Hassimotto, N. M. A., Dos Santos, R. J. and Lajolo, F. M. 2005. Effects of temperature on the chemical composition and antioxidant activity of three strawberry cultivars. Journal of Food Chemistry, 91: 113-121.

Darnel, R. L., Cantliffic, D. J., Kirschbaum, D. S. and Chandler, C. K., 2003. The Physiology flowering in strawberry. Horticulture Review, 28(6): 328-332.

Dubois, M., Gilles, K. A., Hamilton, J. K., Rebers, P. A. and Fred Smith 1956. Determination of sugars and related substances. Application of analytical chemistry, 28(3): 350-356. 


\section{Effect of storage period on the chemical composition}

F.A.O. 2009. National Agriculture Statistics Service, U.S. Reddy, A. H. and Chikkasubbanna, V. 2009. Studies on the Department of Agriculture.

Hannum, S. P, 2004. Impact of strawberries on human health, A Review of Science Nutritional Sciences, 44: 1-17.

Malik, E.P. and Singh, M.B. 1980. Plant Enzymology and Hittoenzymology In: Kalyani Publishers (1) New Delhi, pp: 286.

Miller, G.L., 1972. Use of dinitro-salicylic acid reagent for determination of reducing sugar.

Journal of Annual Chemistry, 31: 426-428.

Nunes, M. C. N., Brecht, J. K., Morais, A.M.M. A., Sargent, S.A. 1995. Physical and chemical quality characteristics of strawberries after storage are reduced by a short delay to cooling. Journal of Post Harvest Bio. and Technology, 6: $17-28$.

Ranganna, S. 1995. Handbook of Analysis and Quality Control for fruit and vegetable products. In: Tata Mc. Graw Hill Pub.Co.Ltd (2) New delhi, India, pp $11-12$. storage behaviour of amla syrup. The Asian Journal of Horticulture, 3(2): 203-207.

Salari, H., Sreenivas, K. N., Shankarappa, T. H., Krishna, K. C. and Gowda, K. P. H. 2012. Journal of Environment \& Ecology, 30(3C): 1052-1057.

Shaheel, S. K., Swami, D. V., Prasanna Kumar, B. and Uma Krishna, K. 2015. Effect of lending of karonda juice with guava.papaya and pineapple juice on its quality and organoleptic evaluation. Journal of Plant Archives, 15(1): 187-192.

Tiwari, D. K. and BhagwanDeen. 2014. Studies on development of squash from bael (Aegle marmelos Correa.) pulp and aloe vera (Aloe barbandensis Miller.) gel blend. Annals of Agriculture and Biotechnology Research, 19(3): 483-487.

Totad, M., Ramkrishna, B. M. and Sreenivas, K. N. 2014. Sapota syrup blended with jackfruit and avocado. Journal of Progressive Agriculture, 5(1): 234-238. 